\title{
THE EFFECT OF DEBT POLICY ON COMPANY VALUE IN THE PULP AND PAPER SUB SECTOR LISTED ON BEI
}

\author{
Alfin Akuba ${ }^{1}$ \\ ${ }^{1}$ Management, Ichsan University Gorontalo, Gorontalo \\ Email: *alfinakuba92@gmail.com
}

Received: 2021-09-06; Received in revised from: 2021-09-13; Accepted: 2021-10-18

\begin{abstract}
Abstrak
Penelitian ini bertujuan untuk mengetahui dan menganalisis seberapa besar pengaruh Kebijakan Hutang (X) secara parsial terhadap Nilai Perusahaan (Y). Penelitian adalah penelitian kuantitatif, dengan menggunakan analisis rasio. Metode analisis menggunakan regresi linier sederhana. Hasil penelitian menunjukkan bahwa Kebijakan Hutang (X)) secara parsial tidak berpengaruh signifikan terhadap Nilai Perusahaan (Y) pada sub sektor Pulp dan Paper yang Go Public di Bursa Efek Indonesia hal ini dapat dilihat dari nilai Thitung 0,774 < Ttabel 2,032.
\end{abstract}

Kata Kunci: Kebijakan Hutang, Nilai Perusahaan

\begin{abstract}
This study aims to determine and analyze how much influence the Debt Policy (X) partially affects Firm Value (Y). This research is a quantitative study, using ratio analysis. The analysis method uses simple linear regression. The results showed that the Debt Policy (X)) partially has no significant effect on Company Value (Y) in the Pulp and Paper sub-sector that is Go Public on the Indonesia Stock Exchange, this can be seen from the value Tcount $0.774<$ Ttable 2.032.
\end{abstract}

Keywords: Debt Policy and Company Value

\section{Introduction}

The commercial sector is an important role for development, whether it is government development through state-owned enterprises or the private sector. Many companies compete to improve the quality of the company so that they can compete in the market and attract consumers. It is best to use various methods. The success of a company can only be achieved through good management, one of which is by increasing the value of the company, the prosperity of the owner of the company, and the stock market price. Therefore, the company must develop a strategic plan regarding its financial aspects [1].

Company is a business entity in any form, a gathering place for workers, capital, natural resources, and entrepreneurship, which aims to obtain maximum profit or profit. By obtaining maximum profit, the company can survive and continue to develop and provide benefits for the owner for the welfare of the company owner. Companies must employ experts or professionals as managers and commissioners to manage the company in order to pay attention to the company's operations and financial activities. Because in today's era of increasingly fierce global competition, companies must improve their competitiveness in domestic and foreign markets to achieve company goals, especially listed companies. By employing experts and professional management personnel, it is hoped that the company's performance will be safer and able to survive and compete in domestic and foreign markets. 
The value of the company can be defined as a reflection of the value of the assets that will be owned by the company at the time of sale. [2], firm value is defined as the price that potential investors are willing to pay when they are willing to sell the company. Firm value is the price potential buyers are willing to pay when selling the company. The higher the value of the company, the more prosperity the owner of the company will enjoy. Firm value can represent the value of assets (such as securities) owned by the company [3].

Value is very important because it reflects the company's performance and affects investors' perceptions of the company. The value of the company will show the prosperity of shareholders. The higher the value of the company, the richer the shareholders [4].

Firm value is the result of many aspects of management, including net cash flow from investment decisions, growth and cost of capital. For investors, firm value is an important concept, because firm value is an indicator of how the market evaluates the firm as a whole [5]. High company value is the desire of the owner of the company because it has a high value, indicating that the welfare of shareholders is also high. In this study, the firm value variable is expressed as the ratio of price to book (PBV) because PBV is widely used in investment decisions. The PBV describes the market's emphasis on the book value of a company's stock. Well-managed companies usually have a PBV higher than 1, which means that the market value of the stock is greater than the book value.

Factors that can affect the value of the company is debt policy. Wise investors will see an increase in company value due to the use of large debt, in other words, investors see debt as a signal of company value [6]. firm value is influenced by debt policy (DER).

This study is aimed at companies in the pulp and paper industry and is publicly listed on the Indonesia Stock Exchange. The pulp and paper industry has made a major contribution to the national economy. In 2018, this industry contributed $17.6 \%$ to the non-oil and gas processing industry and $6.3 \%$ to the national processing industry. The GDP of the pulp and paper industry is growing every year. In the same year, the industry increased $1.1 \%$ year-on-year. It is expected that the pulp and paper industry will grow by 5\% in 2019. The Indonesian Pulp and Paper Association (APKI) estimates that global and domestic demand will continue to grow at a rate of $2 \%$ (year-on-year) (https://analysis. kontan.co.id)

However, due to the decline in global pulp prices, the value of pulp and paper exports from January to May 2019 was US $\$ 2.75$ billion, a $2.48 \%$ year-on-year decline to US $\$ 2.82$ billion. According to data from the Ministry of Environment and Forestry (KLHK), the value of paper exports from January to April 2019 fell 2.05\% to US\$1.43 billion, compared to US $\$ 1.46$ billion in the same period last year. At the same time, the pulp export volume from January to April 2019 was US\$ 880.3 million, down $0.71 \%$ from US\$ 872.1 million in the same period last year. Liana Bratasida, executive director of the Indonesian Pulp and Paper Association (APKI), said that wa the decline in pulp and paper exports was caused by fluctuations in pulp prices due to fluctuations in global market prices (https://ekonomi.bisnis.com).

\subsection{Literature review}

1. Debt policy

Debts are all financial obligations that have not been carried out by the company to other parties. Debt is a source of capital or company capital. Financing decisions include other sources of funds used by the company to run the business. In terms of the financing structure, if the company uses loans or debt as a source of financing other than its own capital, it is said that the company uses debt [7].

Understanding debt policy is a policy adopted by management to obtain company sources of funds so that they can be used to fund company operations [8]. Debt policy is a company policy regarding the extent to which companies use debt funds [9]. 


\section{Company value}

Understanding the value of the company [10] This is the price that potential buyers are willing to pay when the company sells. The higher the value of the company, the more prosperity the owner of the company will enjoy. According to Suad [11] Firm value is the price potential buyers are willing to pay. Firm value is defined as investors' perception of the company's level of success in managing its resources.

Firm value is the result of management work in various fields (ie, net cash flow, growth and cost of capital). The indicator of company value is the stock price. The higher the stock price, the higher the value of the company. You can see a company's value by calculating its price to book ratio (PBV) [5].

\section{Method}

The research method used in this research is descriptive method. Descriptive research is research that aims to explain the existence of phenomena by using numbers to explain the characteristics of individuals or groups. This study assesses the nature of the situation [12]. The population of this study are all publicly released in the pulp and paper sub-sector on the Indonesia Stock Exchange, and there are 7 companies. Data collection uses the recording method, which is to clarify and classify written materials related to research questions to study the required documents or data, and then record and calculate. Document data in the form of financial reports from 7 pulp and paper sub-sectors listed on the Indonesia Stock Exchange, including balance sheets and company income statements.

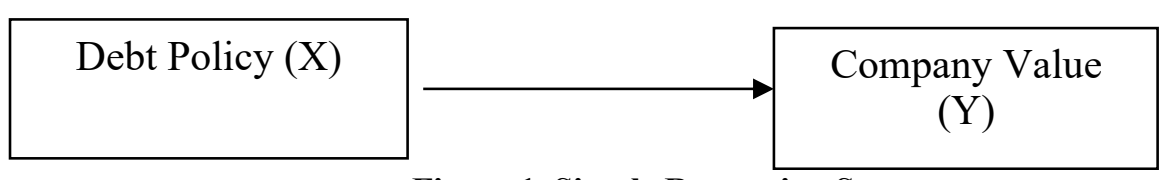

Figure 1. Simple Regression Structure

\section{Results and Discussion}

Tabel 1. Simple Regression Test

\begin{tabular}{|c|c|c|c|c|c|c|}
\hline \multicolumn{7}{|c|}{ Coefficients $^{\mathbf{a}}$} \\
\hline \multirow{3}{*}{\multicolumn{2}{|c|}{ Model }} & \multicolumn{5}{|c|}{ Standardized } \\
\hline & & \multicolumn{2}{|c|}{ Unstandardized Coefficients } & Coefficients & \multirow[b]{2}{*}{$\mathrm{T}$} & \multirow[b]{2}{*}{ Sig. } \\
\hline & & $\mathrm{B}$ & Std. Error & Beta & & \\
\hline \multirow[t]{2}{*}{1} & (Constant) & .798 & 1.319 & & .605 & .549 \\
\hline & Debt Policy & .006 & .007 & .133 & .774 & .445 \\
\hline
\end{tabular}

a. Dependent Variable: Company Value

Source: Processed Data SPSS 24, 2020

$$
\mathrm{Y}=0.798+0,006 \mathrm{X}+0,867 \mathrm{e}
$$

From the regression function above, we can see that if the debt policy variable is increased by a unit score, the regression coefficient marked as positive indicates an immediate change, then the firm value will increase.

1. Constant $(\alpha=0.978)$

If the debt policy $(\mathrm{X})$ is worth $(0)$, then the firm value $(\mathrm{Y})$ is still worth 0.978 . 
2. Debt policy regression coefficient $(\beta=0.006)$ indicates that for every $1 \%$ increase in debt policy, firm value will increase by $0.006 \%$.

3. Efsilon (ع) 0.867. Variables that are not tested but have an impact on (Y) are $86.7 \%$.

Tabel 3. Partial Test

\begin{tabular}{|c|c|c|c|c|c|c|}
\hline \multicolumn{7}{|c|}{ Coefficients $^{\mathrm{a}}$} \\
\hline \multirow[b]{3}{*}{ Model } & & \multirow{2}{*}{\multicolumn{2}{|c|}{ Unstandardized Coefficients }} & Standardized & \multirow[b]{3}{*}{$\mathrm{t}$} & \multirow[b]{3}{*}{ Sig. } \\
\hline & & & & Coefficients & & \\
\hline & & $\mathrm{B}$ & Std. Error & Beta & & \\
\hline \multirow[t]{2}{*}{1} & (Constant) & .798 & 1.319 & & .605 & .549 \\
\hline & Debt Policy & .006 & .007 & .133 & .774 & .445 \\
\hline
\end{tabular}

a. Dependent Variable: Company Value

Source: Processed Data SPSS 24, 2020

According to the table above, for the debt policy variable, the significance value of 0.445 is greater than the alpha value of 0.05 . Because this significance level is greater than 0.05 , it can be concluded that debt policy has no significant effect on firm value.

Based on the results of the study, it was proven that the Debt Policy had no significant effect on the value of the company in the pulp and paper sub-sector that went public on the Indonesia Stock Exchange. The results of the study are in line with the theory presented by Imam [13]. It shows that a lower DER means that the company uses more of its own funds than debt. The higher the DER level, the more debt financing the company has compared to its own funds. It also shows that the company has a great dependence on creditors. DER does not have a significant impact on firm value, which means that the size of the firm's debt will not actually affect firm value. If debt is managed well, companies with higher liabilities can have a higher firm value, so the company has a larger market capitalization asset. Similarly, if the firm's debt level is low and the firm's market value is high, then the firm's value may also be high. Therefore, the scale of the company's debt will not significantly affect the value of the company. This is in line with the theory put forward by Sudana [6], which states that the value of the company will not change regardless of the amount of debt used by the company in company expenses.

The results of this study are consistent with previous research by Prasetia [14] on capital structure, firm size, and firm value risk. The results showed that the capital structure as measured by DER had no significant effect on firm value. According to Lubis [15], other research findings support this study. The title of this research is the impact of profitability, capital structure and liquidity on firm value. The results showed that the capital structure as measured by DER had no significant effect on firm value.

Previous research is the same as the results according to Dwi [16]. The name of this research is the effect of financial ratio activities on firm value (research on manufacturing). The results show that the debt equity ratio (DER) has no significant effect on firm value.

\section{Conclussion}

Based on the results of data analysis and statistical hypothesis testing in this study, it can be concluded that debt policy has no significant effect on firm value in the Pulp and Paper sub-sector listed on the Indonesia Stock Exchange.

\section{References}

[1] L. Yulianti, "Pengaruh Keputusan Keuangan Dan Struktur Kepemilikan Terhadap Nilai 
Perusahaan (Studi Empiris Pada Perusahaan Manufaktur yang Terdaftar Di Bursa EfekIndonesia (BEI) Periode 2007 - 2011)," Universitas Muhammadiyah Surakarta, 2014.

[2] Agus Sartono, Manajemen Keuangan Teori dan Aplikasi. Yogyakarta: BPFE, 2012.

[3] S. Husnan, Manajemen Keuangan: Teori dan Penerapan, Pertama. Yogyakarta: BPFE Yogyakarta, 2008.

[4] S. Fenandar, I., Gany dan Raharja, "Pengaruh Keputusan Investasi, Keputusan Pendanaan, dan Kebijakan Deviden Terhadap Nilai Perusahaan,” J. Akunt., vol. 1, no. 2, pp. 01-10, 2012.

[5] A. H. Prasetyo, Valuasi Perusahaan. Jakarta: PPM, 2011.

[6] I Made Sudana, Manajemen Keuangan Perusahaan. Jakarta: Erlangga, 2015.

[7] M. Tiara, "Pengaruh Hutang Dan Earnings Per Share Terhadap Harga Saham Pada Perusaaan Farmasi Yang Terdaftar Di Bursa Efek Indonesia (BEI) Tahun 2007-2013," Fakultas Ekonomi dan Bisnis Universitas Lampung, 2015.

[8] Bambang Riyanto, Dasar-Dasar Pembelanjaan Perusahaan. Yogyakarta: BPFE Yogyakarta, 2013.

[9] Martono and A. Harjito, Manajemen Keuangan. Yogyakarta: Ekonisia, 2010.

[10] S. Husnan, Manajemen Keuangan: Teori dan Penerapan. Yogyakarta: BPFE, 2015.

[11] Ranupandojo and Suad Husnan, Manajemen Personalia. Yogyakarta: BPFE, 2011.

[12] Sugiyono, Metode Penelitian Pendekatan Kuantitatif dan Kualitatif dan R\&D. Bandung: Alfabeta, 2015.

[13] I. Rahmantio, M. Saifi, and F. Nurlaily, "Pengaruh Debt to Equity Ratio, Return on Equity, Return on Asset dan Ukuran Perusahaan Terhadap Nilai Perusahaan (Studi pada Perusahaan Pertambangan yang Terdaftar di Bursa Efek Indonesia Tahun 2012-2016)," J. Adm. Bisnis, vol. 57, no. 1, pp. 151-159, 2018.

[14] T. E. Prasetia, P. Tommy, and I. S. Saerang, "Struktur Modal, Ukuran Perusahaan Dan Risiko Perusahaan Terhadap Nilai Perusahaan Otomotif Yang Terdaftar Di Bei," Ukuran ... J. EMBA, vol. 8792, no. 2, pp. 879-889, 2014.

[15] I. L. Lubis, B. M. Sinaga, and H. Sasongko, "Effect of Profitability,Capital Structures, and Liquidity to the Value of the Company," J. Apl. Bisnis dan Manaj., vol. 3, no. 3, pp. 458-465, 2017.

[16] A. Dwi, "Pengaruh Aktivitas Rasio Keuangan Terhadap Nilai Perusahaan (Studi Pada Industri Manufaktur)," STIE Semarang, vol. 9, no. 1, pp. 35-53, 2017. 